\title{
Symbiotic Efficiency, Productivity and Profitability of Soybean as Influenced by Liquid Bio-inoculants and Straw Mulch
}

\author{
Neha Rahangdale ${ }^{1}$, Narendra Kumawat ${ }^{2} \varangle\left(\right.$ O M. M. Jadav² , D. V. Bhagat ${ }^{2}$, Mahender Singh ${ }^{3}$ and R. K. Yadav ${ }^{4}$ \\ ${ }^{1}$ Dept. of Agronomy, College of Agriculture, Rajmata Vijayaraje Scindia Krishi Vishwa Vidyalaya, Indore, M. P. (452 001), India \\ ${ }^{2}$ AICRP for Dryland Agriculture, Indore, Madhya Pradesh (452 001), India \\ ${ }^{3}$ Krishi Vigyan Kendra, Dewas, Madhya Pradesh (455 111), India \\ ${ }^{4}$ Krishi Vigyan Kendra, Alirajpur, Madhya Pradesh (457 887), India
}

O
(D) 000
ABs

Open Access

Corresponding $\bigotimes$ kumawatandy@gmail.com

0000-0003-3873-3122

\begin{abstract}
field experiment was conducted at College of Agriculture (RVSKVV), Indore during kharif (July-October) 2019 to study - on physiological parameter, symbiotic efficiency, productivity and profitability of soybean as influenced by liquid bioinoculants and mulch under Vertisols in relation to ten treatments. Results revealed that the higher growth attributes, physiological parameters and symbiotic parameters were recorded under Rhizobium +phosphours solubilizing bacteria (PSB)+mulch+foliar spray of Plant Growth Promoting Rhizobacteria (PGPR) @ $20 \mathrm{ml} \mathrm{l}^{-1}$ water in comparison to other treatments. The highest seed yield $\left(1232 \mathrm{~kg} \mathrm{ha}^{-1}\right)$, straw yield $\left(1537 \mathrm{~kg} \mathrm{ha}^{-1}\right)$, protein content $(41.72 \%)$ and protein yield $\left(51628 \mathrm{~kg} \mathrm{ha}^{-1}\right)$ were obtained

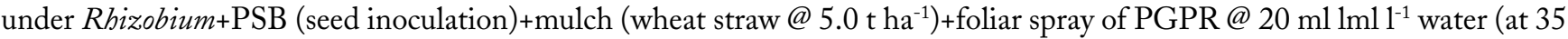
days and flowering stage), which was at par with Rhizobium+mulch+foliar spray of PGPR @ $10 \mathrm{ml} \mathrm{l}^{-1}$ water, PSB +mulch+foliar spray of PGPR@ $15 \mathrm{mll}^{-1}$ water and Rbizobium+PSB +mulch. The maximum gross returns (₹ $48768 \mathrm{ha}^{-1}$ ), net returns (₹ 20762 $\left.\mathrm{ha}^{-1}\right), \mathrm{B}: \mathrm{C}$ ratio (1.74), production efficiency $\left(14.0 \mathrm{~kg} \mathrm{ha}^{-1} \mathrm{day}^{-1}\right)$ and economic efficiency (₹ $\left.235.93 \mathrm{ha}^{-1}\right)$ were also recorded under above treatment. Significantly higher nutrient uptake (82.61 and $35.31 \mathrm{~kg} \mathrm{~N}, 4.72$ and $8.49 \mathrm{~kg}$ P, 24.17 and $41.27 \mathrm{~kg} \mathrm{~K}$ by seed and straw, respectively) were obtained under Rbizobium+PSB+mulch +foliar spray of PGPR @ $20 \mathrm{ml}^{-1}$ water.
\end{abstract}

KEYWORDS: Bio-inoculants, nutrient uptake, physiological parameters, symbiotic efficiency, yield

Citation (VANCOUVER): Rahangdale et al., Symbiotic Efficiency, Productivity and Profitability of Soybean as Influenced by Liquid Bio-inoculants and Straw Mulch. International Journal of Bio-resource and Stress Management, 2022; 13(1), 9-16. HTTPS://DOI. ORG/10.23910/1.2022.2345.

Copyright: (c) 2022 Rahangdale et al. This is an open access article that permits unrestricted use, distribution and reproduction in any medium after the author(s) and source are credited.

Data Availability Statement: Legal restrictions are imposed on the public sharing of raw data. However, authors have full right to transfer or share the data in raw form upon request subject to either meeting the conditions of the original consents and the original research study. Further, access of data needs to meet whether the user complies with the ethical and legal obligations as data controllers to allow for secondary use of the data outside of the original study.

Conflict of interests: The authors have declared that no conflict of interest exists.

RECEIVED on $09^{\text {th }}$ May 2021 RECEIVED in revised form on $15^{\text {th }}$ December 2021 ACCEPTED in final form on $09^{\text {th }}$ January 2022 PUBLISHED on $25^{\text {th }}$ January 2022 


\section{INTRODUCTION}

Soybean (Glycine max L. Merrill) being a leguminous crop, is capable to fix atmospheric nitrogen through biological nitrogen fixation and originated from China (Tomar et al., 2018 and Rahangdale et al., 2021). It is basically a legume crop, however, nowadays it is gaining popularity as an oilseed crop. Soybean grains are important as protein meal and vegetable oil (Virk et al., 2018a). Among the essential nutrients, macro-nutrients such as nitrogen, phosphorus and potassium play a crucial role in improving plant growth and yield (Singh et al., 2020). Soybean crop played a pivotal role in solving the problem of malnutrition as it contains about 20 percent oil and 40 percent high quality protein. Its protein is rich in valuable amino acid lycine (5\%), in which, most of the cereals are deficient (Kumawat et al., 2019). In addition, it is an important source of $\mathrm{K}, \mathrm{Ca}, \mathrm{Zn}, \mathrm{Fe}, \mathrm{B}$, and $\mathrm{P}$. Its oil containing saturated fatty acids, like palmitic $(12-13 \%$ of total oil) and stearic (3-4\%) and unsaturated fatty acids such as oleic (19-23\%), linoleic (48-58\%) and linolenic (5-8\%) (Khandkar et al., 2019). World soybean production is 341.76 million tonnes which is $4.17 \%$ less than the last year's soybean production (Anonymous, 2019-20). India ranks $6^{\text {th }}$ rank in the world with respect to production after Brazil, United States, Argentina, China and Paraguay. In India it is cultivated in 10.16 million hectares, producing 8.35 million tonnes with average productivity of $822 \mathrm{~kg} \mathrm{ha}^{-1}$. Madhya Pradesh is the leading state in India grown on an area of 5.01 million hectares and production of 5.40 million tonnes with productivity of $858 \mathrm{~kg} \mathrm{ha}^{-1}$ (Anonymous, 2018). Madhya Pradesh has substantial contribution around 60\% of total area and production of India, which is why it is also known, as "Soya State" (Tomar et al., 2018).

The productivity of soybean can be increased by inoculation of bio-fertilizers and which have shown better results in sustaining the crop productivity and improving soil fertility (Kumar et al., 2020a). Rbizobium can add $20-200 \mathrm{~kg} \mathrm{~N} \mathrm{ha}^{-1}$ under optimum soil conditions and thereby increased crop yield by $15-25 \%$ of crop yield (Htwe et al., 2019 and Singh et al., 2020). PGPRs improve the growth either through using their self metabolism (solubilizing phosphates, producing hormones or fixing nitrogen) or directly affecting the plant metabolism (enhancing the uptake of nutrients and water), enhanced root system, increasing the enzymatic activities or "helping" other beneficial micro-organisms to improves their action on the plants. It's may also promote plant growth by suppressing plant pathogens (Kumawat et al., 2017 and Kumar et al., 2021). Mulching is a desirable management practice which regulates farm environment and thereby enhances crop production through regulating soil temperature by reducing leaching and evapotranspiration, by increasing the soil organic matter content and by reducing nutrient loss due to run off (Sikka et al., 2018, Virk et al., 2018b and Virk et al., 2019). Organic mulches like wheat straw are easily available in nature at affordable prices and are easily degradable in nature after their use. Application of mulches good source of crop nutrition over a period in crop growth, suppress weeds and reduces evaporation loss in the aerobic system (Praharaj et al., 2017 and Kumar et al., 2020b). Mulches can improve water productivity and yields through an increase in the water holding capacity of soils (Rinku et al., 2016 and Jadav et al., 2021). It improve the moisture availability period, reduce evaporation loss and also stabilize soil temperature (Dhyani et al., 2016, Kumawat et al., 2020, Praharaj et al., 2020 and Kumawat et al., 2021). So, keeping in view the above observations, present investigation on the physiological parameter, symbiotic efficiency, productivity and profitability of soybean as influenced by liquid bio-inoculants and mulch under Vertisols has been undertaken.

\section{MATERIALS AND METHODS}

A field experiment was carried out at Research Farm, at $75^{\circ} 48^{\prime}$ East longitude and $22^{\circ} 43^{\prime}$ North latitude with an altitude of 567 meters above mean sea level during kharif season of (July to October) 2019 on a medium to black soil with $\mathrm{pH}$ of 7.8 and organic carbon 0.34 percent. The soil was low in available nitrogen $\left(245.0 \mathrm{~kg} \mathrm{ha}^{-1}\right)$ medium in available phosphorus $\left(12.30 \mathrm{~kg} \mathrm{ha}^{-1}\right)$ and high in potassium $\left(480.2 \mathrm{~kg} \mathrm{ha}^{-1}\right)$. The treatment were laid out in RBD in three replications with twelve treatments viz., $\mathrm{T}_{1}$ : Control, $\mathrm{T}_{2}$ : Rbizobium (seed inoculation), $\mathrm{T}_{3}$ : PSB (seed inoculation), $\mathrm{T}_{4}$ : Rhizobium $+\mathrm{PSB}$ (seed inoculation), $\mathrm{T}_{5}$ : Rbizobium (seed inoculation)+mulch (wheat straw @ $5.0 \mathrm{t} \mathrm{ha}^{-1}$ ), $\mathrm{T}_{6}$ : PSB (seed inoculation)+mulch (wheat straw @ $\left.5.0 \mathrm{t} \mathrm{ha}^{-1}\right), \mathrm{T}_{7}$ : Rhizobium+PSB (seed inoculation)+mulch (wheat straw @ $\left.5.0 \mathrm{t} \mathrm{ha}^{-1}\right), \mathrm{T}_{8}$ : Rbizobium (seed inoculation)+mulch (wheat straw@5.0 t ha ${ }^{-1}$ )+foliar spray of PGPR@10 ml $1^{-1}$ water (at 35 days and flowering stage), $T_{9}$ : PSB (seed inoculation)+mulch (wheat straw @ $5.0 \mathrm{t} \mathrm{ha}^{-1}$ )+foliar spray of PGPR@15 ml 1-1 water (at 35 days and flowering stage) and $\mathrm{T}_{10}$ : Rbizobium+PSB (seed inoculation)+mulch (wheat straw@5.0 t ha-1)+foliar spray of PGPR@ $20 \mathrm{ml}$ $1^{-1}$ water (at 35 days and flowering stage). Seeds of the crop (JS-20 34) were sown on 30 June 2019 and harvested on 25 September 2019. The recommended dose of fertilizer (30 kg N+60 kg P $\mathrm{O}_{5}+30 \mathrm{~kg} \mathrm{~K}_{2} \mathrm{O} \mathrm{ha}^{-1}$ ) was applied to the soybean. A full dose of $\mathrm{N}, \mathrm{P}_{2} \mathrm{O}_{5}$ and $\mathrm{K}_{2} \mathrm{O}$ were applied at the time of sowing. Recommended local crop management practices, weed control measures and plant protection measures were done in the crops. Various growth and yield attributes were observed at harvest following the standard procedure. The net plot seed yield was converted to seed 
yield in terms of $\mathrm{kg} \mathrm{ha}^{-1}$. Protein content in seed was worked out by multiplying the nitrogen content in the seed with the factor by (Anonymous, 1960). Protein harvest was determined by multiplying the protein content in seed and straw with their respective yield. Prevailing market prices of inputs as per treatments of each crop was considered for working out the cost of cultivation. Net returns $\left(₹ \mathrm{ha}^{-1}\right)$ was calculated by deducting the cost of cultivation (₹ $\mathrm{ha}^{-1}$ ) from gross returns, while $\mathrm{B}: \mathrm{C}$ ratio were worked out as a ratio of gross return (₹ ha $\left.\mathrm{h}^{-1}\right)$ to cost of cultivation ( $\left(\mathrm{ha}^{-1}\right)$ suggested by Kumawat et al. (2015).

Nitrogen fixation capacity was computed by the formula given Carter and Rennie (1984) which is expressed as:

Nitrogen fixation capacity $=($ TNCIP-TNCIC $) / T N C I P) \times$ 100

Where:

TNCIP=Total nitrogen content in inoculated plant

$\mathrm{TNCIC}=$ Total nitrogen content in control plant

Nutrient uptake by seed and straw of crop was calculated in $\mathrm{kg} \mathrm{ha}^{-1}$ in relation to dry matter production/ha by using the formula. trient uptake $\left(\mathrm{kg} \mathrm{ha}^{-1}\right)=($ Nutrient content $(\%) \times$ yield $\left(\mathrm{seed} / \mathrm{straw}\right.$ in $\left.\mathrm{kg} \mathrm{ha}^{-1}\right) \times 100$

Production efficiency and economic efficiency were calculated as following the formula suggested by Kumar et al. (2014a).

Production efficiency $\left(\mathrm{kg} \mathrm{ha}^{-1} \mathrm{day}^{-1}\right)=$ Seed yield $\left(\mathrm{kg} \mathrm{ha}^{-1}\right) /$ The total duration taken crop (days)

Economic efficiency $\left(₹ \mathrm{ha}^{-1} \mathrm{day}^{-1}\right)=\operatorname{Net}$ return $\left(₹ \mathrm{ha}^{-1}\right) /$ Total duration taken crop (days)

All the data obtained from the trial was statistically analyzed using the F-test (Gomez and Gomez 1984). Critical difference $(C D)$ values at $p=0.05$ were used to determine the significance of differences between mean values of treatments.

\section{RESULTS AND DISCUSSION}

\subsection{Growth and physiological parameters}

The growth characters (plant height, branches plant ${ }^{-1}$, dry matter accumulation plant ${ }^{-1}$ ) and physiological parameters (leaf area, leaf area index, CGR, RGR, chlorophyll content) were significantly affected by liquid bio-inoculants and mulching during the investigation (Table 1). Significantly

Table 1: Effect of liquid bio-inoculants and mulch on growth and physiological parameters of soybean

\begin{tabular}{lcccccccc}
\hline Treatments & $\begin{array}{c}\text { Plant } \\
\text { height } \\
(\mathrm{cm})\end{array}$ & $\begin{array}{c}\text { Branches } \\
\text { plant }^{-1}\end{array}$ & $\begin{array}{c}\text { Dry matter } \\
\text { accumulation } \\
\text { plant }\end{array}$ & $\begin{array}{c}\text { Leaf area } \\
\left(\mathrm{cm}^{2}\right)\end{array}$ & $\begin{array}{c}\text { Leaf area } \\
\text { index }\end{array}$ & $\begin{array}{c}\text { CGR } \\
\left(\mathrm{g} \mathrm{plant}^{-1}\right. \\
\left.\text { day }^{-1}\right)\end{array}$ & $\begin{array}{c}\text { RGR } \\
\left(\mathrm{g} \mathrm{g}^{-1}\right. \\
\left.\text { plant }^{-1}\right)\end{array}$ & $\begin{array}{c}\text { Chlorophyll } \\
\text { content (SPAD } \\
\text { value) at 60 DAS }\end{array}$ \\
\hline $\mathrm{T}_{1}$ & 41.95 & 4.03 & 17.80 & 47.86 & 0.120 & 0.078 & 0.022 & 37.99 \\
$\mathrm{~T}_{2}$ & 44.90 & 4.38 & 20.17 & 48.81 & 0.122 & 0.082 & 0.025 & 39.27 \\
$\mathrm{~T}_{3}$ & 43.77 & 4.24 & 19.33 & 48.63 & 0.122 & 0.082 & 0.025 & 39.13 \\
$\mathrm{~T}_{4}$ & 45.17 & 5.00 & 21.10 & 50.33 & 0.126 & 0.092 & 0.030 & 40.53 \\
$\mathrm{~T}_{5}$ & 46.80 & 5.65 & 21.53 & 52.73 & 0.132 & 0.092 & 0.030 & 41.67 \\
$\mathrm{~T}_{6}$ & 46.74 & 5.62 & 21.48 & 52.48 & 0.131 & 0.092 & 0.030 & 42.31 \\
$\mathrm{~T}_{7}$ & 48.82 & 6.05 & 22.80 & 53.52 & 0.134 & 0.093 & 0.030 & 43.31 \\
$\mathrm{~T}_{8}$ & 49.08 & 6.10 & 23.50 & 54.21 & 0.136 & 0.094 & 0.031 & 44.63 \\
$\mathrm{~T}_{9}$ & 48.89 & 6.02 & 23.48 & 54.14 & 0.135 & 0.096 & 0.032 & 44.09 \\
$\mathrm{~T}_{10}$ & 49.55 & 6.33 & 24.24 & 54.54 & 0.136 & 0.098 & 0.034 & 44.46 \\
$\mathrm{SEm} \pm$ & 1.59 & 0.33 & 1.27 & 1.64 & 0.004 & 0.01 & 0.003 & 1.50 \\
$\mathrm{CD}(p=0.05)$ & 4.73 & 0.97 & 3.78 & 4.86 & 0.012 & 0.02 & 0.009 & 4.47 \\
\hline
\end{tabular}

$\mathrm{T}_{1}$ : Control; $\mathrm{T}_{2}$ : Rhizobium (seed inoculation); $\mathrm{T}_{3}: \mathrm{PSB}$ (seed inoculation); $\mathrm{T}_{4}:$ Rbizobium $+\mathrm{PSB}$ (seed inoculation); $\mathrm{T}_{5}$ : Rhizobium (seed inoculation)+mulch (wheat straw @ $\left.5.0 \mathrm{t} \mathrm{ha}^{-1}\right) ; \mathrm{T}_{6}: \mathrm{PSB}$ (seed inoculation)+mulch (wheat straw @ $5.0 \mathrm{t}$ ha $\left.^{-1}\right) ; \mathrm{T}_{7}$ :Rhizobium+PSB (seed inoculation)+mulch (wheat straw @ $\left.5.0 \mathrm{tha}^{-1}\right) ; \mathrm{T}_{8}:$ Rhizobium (seed inoculation)+mulch (wheat straw @ $5.0 \mathrm{t} \mathrm{ha}^{-1}$ )+foliar spray of PGPR@ $10 \mathrm{ml} \mathrm{l}^{-1}$ water (at 35 days and flowering stage); $\mathrm{T}_{9}$ : PSB (seed inoculation)+mulch (wheat straw @ $\left.5.0 \mathrm{t} \mathrm{ha}^{-1}\right)+$ foliar spray of PGPR @ $15 \mathrm{ml}^{-1}$ water (at 35 days and flowering stage); $\mathrm{T}_{10}$ :Rhizobium+PSB (seed inoculation)+mulch (wheat straw @ $\left.5.0 \mathrm{t} \mathrm{ha}^{-1}\right)+$ foliar spray of PGPR @ $20 \mathrm{ml} \mathrm{l}^{-1}$ water (at 35 days and flowering stage) 
higher plant height $(49.55 \mathrm{~cm})$, branches plant ${ }^{-1}(6.33)$ and dry matter accumulation plant ${ }^{-1}(24.24 \mathrm{~g})$ were found with the application of Rbizobium+PSB+mulch (wheat straw @ $\left.5.0 \mathrm{t} \mathrm{ha}^{-1}\right)+$ foliar spray of PGPR @ $20 \mathrm{ml} \mathrm{l}^{-1}$ water $\left(\mathrm{T}_{10}\right)$ which was at par with all the treatments except control, Rbizobium and PSB alone. Similarly, the maximum leaf area $\left(54.54 \mathrm{~cm}^{2}\right)$, leaf area index (0.136), RGR $(0.034 \mathrm{~g}$ $\mathrm{g}^{-1}$ plant $^{-1}$ ) and chlorophyll content (44.46 SPAD value) were observed under Rbizobium+PSB+wheat straw mulch @ 5.0 $\mathrm{t} \mathrm{ha}^{-1}+$ foliar spray of PGPR @ $20 \mathrm{ml} \mathrm{l}^{-1}$ water $\left(\mathrm{T}_{10}\right)$ which was statistically at par with rest of the treatments except control, Rbizobium and PSB alone. The increase in growth parameters may be due to the factor of photosynthesis production which was higher due to increased levels of inoculation. The inoculated produced more and healthy nodules which in turn translocation nitrogen from, the lower to the growing tips and enlarged the height of the plant. The combined application of bio-inoculants and mulch provided nutrients to the plants and mulch helps in maintaining adequate soil moisture which helps in reduces stomatal closure; this opens the pathway for the exchange of water, carbon dioxide and oxygen, resulting in increases in photosynthetic rate and thereby increasing vegetative growth of plants. These results are in accordance with the findings of Arora et al. (2011), Jain (2015), Kumar et al. (2020) in pea and Rahangdale et al. (2021) in soybean.

\subsection{Symbiotic parameters}

The symbiotic parameter (total nodules, effective nodules, fresh and dry weight of nodules plant ${ }^{-1}$ ) was significantly influenced by liquid bio-inoculants and mulch (Table 2). The total number of nodules plant ${ }^{-1}$ (26.17), effective nodules plant $^{-1}(19.69)$, fresh weight of nodules plant ${ }^{-1}(703.33 \mathrm{mg})$ and dry weight of nodules plant ${ }^{-1}(132.45 \mathrm{mg})$ were highest in $\left(\mathrm{T}_{10}\right)$ Rhizobium+PSB+mulch @ $5.0 \mathrm{t} \mathrm{ha}^{-1}+$ foliar spray of PGPR @ $20 \mathrm{ml} \mathrm{l}^{-1}$ water which was on par with rest of the treatments (except $\mathrm{T}_{1}, \mathrm{~T}_{2}, \mathrm{~T}_{3}$ and $\mathrm{T}_{4}$ ) while minimum values these parameters were observed in control $\left(\mathrm{T}_{1}\right)$ where the recommended dose of fertilizer (RDF) was applied. The significantly higher nitrogen fixation capacity was also recorded with the application of Rhizobium $+\mathrm{PSB}+$ mulch @ $5.0 \mathrm{t} \mathrm{ha}^{-1}+$ foliar spray of PGPR @ $20 \mathrm{ml} \mathrm{l}^{-1}$ followed by PSB+wheat straw mulch@ $5.0 \mathrm{t} \mathrm{ha}^{-1}$ along with foliar spray of PGPR@ $15 \mathrm{ml} \mathrm{l}^{-1}$ water and Rhizobium+mulch @ $5.0 \mathrm{t} \mathrm{ha}^{-1}+$ foliar spray of PGPR @ $10 \mathrm{ml} \mathrm{l}^{-1}$ as compared to other treatments. The conjunction of bio-inoculants with

\begin{tabular}{|c|c|c|c|c|c|c|c|c|c|}
\hline Treatments & $\begin{array}{c}\text { Total } \\
\text { nodules } \\
\text { plant }^{-1}\end{array}$ & $\begin{array}{c}\text { Effective } \\
\text { nodules } \\
\text { plant }^{-1}\end{array}$ & $\begin{array}{c}\text { Fresh weight } \\
\text { of nodules } \\
\text { plant }^{-1} \text { (mg) }\end{array}$ & $\begin{array}{l}\text { Dry weight } \\
\text { of nodules } \\
\text { plant }^{-1} \\
(\mathrm{mg})\end{array}$ & $\begin{array}{l}\text { Nitrogen } \\
\text { fixation } \\
\text { capacity } \\
(\%) \\
\end{array}$ & $\begin{array}{c}\text { Seed } \\
\text { yield } \\
\left(\mathrm{kg} \mathrm{ha} \mathrm{ha}^{-1}\right)\end{array}$ & $\begin{array}{c}\text { Straw } \\
\text { yield } \\
\left(\mathrm{kg} \mathrm{ha}^{-1}\right)\end{array}$ & $\begin{array}{c}\text { Protein } \\
\text { content } \\
(\%)\end{array}$ & $\begin{array}{c}\text { Protein } \\
\text { yield } \\
\left(\mathrm{kg} \mathrm{ha}^{-1}\right)\end{array}$ \\
\hline $\mathrm{T}_{1}$ & 19.33 & 13.80 & 473.33 & 93.67 & 0.00 & 864 & 1336 & 36.74 & 31808 \\
\hline $\mathrm{T}_{2}$ & 20.17 & 14.50 & 483.33 & 101.00 & 2.27 & 899 & 1343 & 37.44 & 33655 \\
\hline $\mathrm{T}_{3}$ & 19.83 & 13.83 & 480.00 & 103.33 & 1.90 & 888 & 1336 & 37.40 & 33128 \\
\hline $\mathrm{T}_{4}$ & 21.67 & 16.17 & 573.33 & 109.81 & 4.00 & 937 & 1376 & 38.17 & 35941 \\
\hline $\mathrm{T}_{5}$ & 23.60 & 17.87 & 663.33 & 124.92 & 7.21 & 994 & 1382 & 39.29 & 39060 \\
\hline $\mathrm{T}_{6}$ & 23.43 & 17.62 & 660.67 & 124.54 & 6.33 & 983 & 1375 & 39.00 & 38350 \\
\hline $\mathrm{T}_{7}$ & 24.00 & 19.43 & 687.67 & 129.75 & 8.69 & 1071 & 1457 & 39.94 & 42800 \\
\hline $\mathrm{T}_{8}$ & 25.33 & 19.93 & 696.67 & 131.45 & 11.16 & 1177 & 1519 & 40.92 & 48035 \\
\hline $\mathrm{T}_{9}$ & 25.00 & 19.47 & 687.33 & 129.14 & 10.38 & 1166 & 1510 & 40.57 & 47352 \\
\hline $\mathrm{T}_{10}$ & 26.17 & 19.69 & 703.33 & 132.45 & 12.64 & 1232 & 1537 & 41.72 & 51628 \\
\hline $\mathrm{SEm} \pm$ & 0.92 & 0.65 & 24.22 & 4.65 & 0.23 & 50 & 50 & 1.18 & 2662 \\
\hline $\mathrm{CD}(p=0.05)$ & 2.73 & 1.94 & 71.97 & 13.82 & 0.69 & 149 & 148 & 3.51 & 7910 \\
\hline
\end{tabular}

$\mathrm{T}_{1}$ : Control; $\mathrm{T}_{2}:$ Rhizobium (seed inoculation); $\mathrm{T}_{3}: \mathrm{PSB}$ (seed inoculation); $\mathrm{T}_{4}:$ Rhizobium $+\mathrm{PSB}$ (seed inoculation); $\mathrm{T}_{5}$ : Rhizobium (seed inoculation)+mulch (wheat straw @ $\left.5.0 \mathrm{tha}^{-1}\right) ; \mathrm{T}_{6}:$ PSB (seed inoculation)+mulch (wheat straw @ $5.0 \mathrm{t}$ $\left.\mathrm{ha}^{-1}\right) ; \mathrm{T}_{7}:$ Rhizobium+PSB (seed inoculation)+mulch (wheat straw @ $\left.5.0 \mathrm{tha}^{-1}\right) ; \mathrm{T}_{8}:$ Rhizobium (seed inoculation)+mulch (wheat straw@5.0 t ha ${ }^{-1}$ )+foliar spray of PGPR@ $10 \mathrm{ml} \mathrm{l}^{-1}$ water (at 35 days and flowering stage); $\mathrm{T}_{9}$ : PSB (seed inoculation)+mulch (wheat straw @ $\left.5.0 \mathrm{t} \mathrm{ha}^{-1}\right)+$ foliar spray of PGPR @ $15 \mathrm{ml} \mathrm{l}^{-1}$ water (at 35 days and flowering stage); $\mathrm{T}_{10}$ : Rbizobium+PSB (seed inoculation)+mulch (wheat straw @ $5.0 \mathrm{t} \mathrm{ha}^{-1}$ )+foliar spray of PGPR @ $20 \mathrm{ml} \mathrm{l}^{-1}$ water (at 35 days and flowering stage) 
mulch had a favourable effect on soybean nodulation was increased by 8-220\% in different cropping seasons (Shekon et al., 2005). Similar results were also reported by Kumar et al., (2010), Bhanwaria et al., (2013), Kumar et al., (2014b) and Singh et al., (2020).

\subsection{Productivity}

Seed yield and straw yield of soybean as affect by various bioinoculants and straw mulching (Table 2). Highest seed yield $\left(1232 \mathrm{~kg} \mathrm{ha}^{-1}\right)$ and straw yield $\left(1537 \mathrm{~kg} \mathrm{ha}^{-1}\right)$ was recorded under $\mathrm{T}_{10}$ treatment where Rhizobium+PSB+mulch @ 5.0 t ha ${ }^{-1}+$ foliar spray of PGPR @ $20 \mathrm{ml} \mathrm{l}^{-1}$ water and it was closely followed by Rhizobium +mulch @ $5.0 \mathrm{t} \mathrm{ha}^{-1}$ along with foliar spray of PGPR @ $10 \mathrm{mll}^{-1}$ water (1177 and 1519 $\left.\mathrm{kg} \mathrm{ha}^{-1}\right), \mathrm{PSB}+$ mulch along with foliar spray of PGPR @ 15 $\mathrm{ml} \mathrm{l}^{-1}$ water (1166 and $1510 \mathrm{~kg} \mathrm{ha}^{-1}$ ) and Rbizobium+PSB +mulch@5.0 tha $\left.{ }^{-1}\right)\left(1071\right.$ and $\left.1457 \mathrm{~kg} \mathrm{ha}^{-1}\right)$ were registered 39.12, 36.22, 34.95 and 23.96 percent higher seed yield and 15.04, 13.69, 13.02 and 9.06 percent over control, respectively. It is clear that bio-inoculants (Rhizobium, PSB and PGPRs) solubilize the native sparingly soluble phosphates as well as nutrients in the soil which that might have enhanced the availability of plant nutrients and reducing the fixation in the soil. Thus, greater assimilation of photosynthates and their subsequent partitioning between vegetative and reproductive structures might have helped in enhancing the yield attributing characters and finally yields of soybean. These findings are corroborated with the results of Jain (2015), Tomar et al. (2018), Verma et al. (2017) and Htwe et al. (2019).

\subsection{Quality parameters}

Protein content and their yield were affected by bio- inoculants and straw wheat straw mulch (Table 2). The higher protein content (41.72\%) was obtained with the application of Rhizobium+PSB+mulch@ $5.0 \mathrm{t} \mathrm{ha}^{-1}+$ foliar spray of PGPR @ $20 \mathrm{ml} \mathrm{l}^{-1}$ water, it was at par with each other and significantly superior to control, Rhizobium, PSB and Rhizobium+PSB. Similarly, maximum protein yield was recorded with Rbizobium+PSB+mulch @ $5.0 \mathrm{t} \mathrm{ha}{ }^{-1}+$ foliar spray of PGPR @20 $\mathrm{ml} \mathrm{l}^{-1}$ water, it was found closely followed Rhizobium+wheat straw mulch@ @ $5.0 \mathrm{t} \mathrm{ha}^{-1}+$ foliar spray of PGPR @ $10 \mathrm{ml} \mathrm{l}^{-1}$ water and PSB+wheat straw mulch@ $5.0 \mathrm{t} \mathrm{ha}^{-1}$ along with foliar spray of PGPR @ 10 $\mathrm{ml} \mathrm{l}^{-1}$ water. The protein content in the seed is essentially a manifestation of $\mathrm{N}$ content. Increased $\mathrm{N}$ content due to seed inoculation with bio-inoculants and mulching resulted in higher protein content because of their beneficial role in enhancing $\mathrm{N}$ content in seed. The protein yield is related to seed yield and protein content, seed yield and protein content increased naturally increased the protein yield. Similar, findings have also been reported by Siczek et al. (2015), Htwe et al. (2019) and Rahangdale et al. (2021) in soybean.

\subsection{Profitability}

The economics of soybean were influenced significantly by bio-inoculants, mulch and PGPRs (Table 3). Among the various treatment, maximum gross returns ( $₹ 48,768$ ), net returns (₹ 20,762 ha $\mathrm{ha}^{-1}$, B:C (1.74) ratio, production efficiency $\left(14.0 \mathrm{~kg} \mathrm{ha}^{-1} \mathrm{day}^{-1}\right)$ and economic efficiency (235.93 ₹ $\left.\mathrm{ha}^{-1} \mathrm{day}^{-1}\right)$ were recorded with the supplementation of Rhizobium+PSB+mulch @ $5.0 \mathrm{t} \mathrm{ha}^{-1}+$ foliar spray of PGPR@ $20 \mathrm{ml} \mathrm{l}^{-1}$ water. This was mainly due to higher seed yield, straw yield and net returns and relatively low

Table 3: Effect of liquid bio-inoculants and mulch on economics of soybean

\begin{tabular}{lccccc}
\hline Treatments & $\begin{array}{c}\text { Gross returns } \\
\left(₹ \mathrm{ha} \mathrm{C}^{-1}\right)\end{array}$ & $\begin{array}{c}\text { Net returns } \\
\left(₹ \mathrm{ha} \mathrm{h}^{-1}\right)\end{array}$ & $\begin{array}{c}\mathrm{B}: \mathrm{C} \\
\text { ratio }\end{array}$ & $\begin{array}{c}\text { Production efficiency } \\
\left(\mathrm{kg} \mathrm{ha}^{-1} \mathrm{day}^{-1}\right)\end{array}$ & $\begin{array}{c}\text { Economic efficiency } \\
\left(₹ \mathrm{ha}^{-1} \mathrm{day}^{-1}\right)\end{array}$ \\
\hline $\mathrm{T}_{1}$ & 34722 & 10736 & 1.45 & 9.82 & 121.99 \\
$\mathrm{~T}_{2}$ & 36026 & 11980 & 1.50 & 10.21 & 136.14 \\
$\mathrm{~T}_{3}$ & 35607 & 11561 & 1.48 & 10.09 & 131.38 \\
$\mathrm{~T}_{4}$ & 37503 & 13397 & 1.56 & 10.64 & 152.23 \\
$\mathrm{~T}_{5}$ & 39624 & 13078 & 1.49 & 11.29 & 148.61 \\
$\mathrm{~T}_{6}$ & 39232 & 12686 & 1.48 & 11.17 & 144.15 \\
$\mathrm{~T}_{7}$ & 42661 & 16055 & 1.60 & 12.17 & 182.44 \\
$\mathrm{~T}_{8}$ & 46692 & 19346 & 1.71 & 13.37 & 219.84 \\
$\mathrm{~T}_{9}$ & 46266 & 18560 & 1.67 & 13.25 & 210.90 \\
$\mathrm{~T}_{10}$ & 48768 & 20762 & 1.74 & 14.00 & 235.93 \\
$\mathrm{SEm} \pm$ & 1888 & 1888 & 0.07 & 0.57 & 21.46 \\
$\mathrm{CD}(p=0.05)$ & 5610 & 5610 & 0.22 & 1.70 & 63.76 \\
\hline
\end{tabular}

1US $\$=$ INR 71.02 (Average value for the month October, 2019) 
cost of biofertilizers and micronutrients. The additional cost of organic manures was compensated by the additional yield of soybean. This might be the improvement in growth and yield attributes and the ultimate increase in seed yield could be the reason for enhanced economic parameters in the above treatment. These findings are in conformity with Kumar et al. (2014a), Kalegore et al. (2018) and Jadav et al. (2021).

\subsection{Nutrient uptake}

The nutrients uptake by seed and straw $(\mathrm{N}, \mathrm{P}$ and $\mathrm{K})$ were significantly influenced due to different treatments (Figure 1). Significantly highest $N, P$ and $K$ uptake by seed and straw were recorded in the treatment $\mathrm{T}_{10}$ (Rhizobium $+\mathrm{PSB}+$ mulch @ $5.0 \mathrm{t} \mathrm{ha}^{-1}+$ foliar spray of PGPR @ $20 \mathrm{ml} \mathrm{l}^{-1}$ water), which was statistically at par with Rbizobium+mulch @ $5.0 \mathrm{t} \mathrm{ha}^{-1}+$ foliar spray of PGPR @ $10 \mathrm{ml} \mathrm{l}^{-1}$ water and Rbizobium+mulch@ $5.0 \mathrm{t} \mathrm{ha}^{-1}+$ foliar spray of PGPR @ 15 $\mathrm{ml} \mathrm{l}^{-1}$ over the rest of the treatments. The Rhizobium, PSB and PGPR along with mulch enhanced the availability of nutrients to the plants which might have utilized in greater root development and nodulation which in turn resulted in higher nitrogen fixation in the soil by nodules. Thus, increased availability of macro and micro-nutrients resulted in greater uptake by the plants and ultimately increased their content in plants. Our findings are in agreement with those reported earlier (Kumar et al., 2014b, Rinku et al., 2016 and Kumawat et al., 2020).

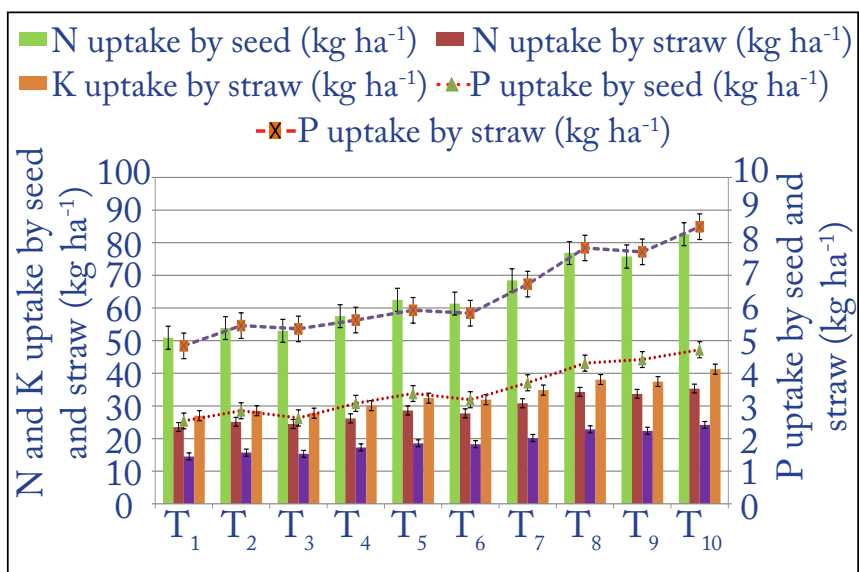

Figure 1: Effect of liquid bio-inoculants and mulch on nutrients uptake by seed and straw

\section{CONCLUSION}

$\mathrm{D}$ ual seed inoculation (Rhizobium+PSB)+wheat straw mulch @ $5.0 \mathrm{t} \mathrm{ha}^{-1}$ along with two foliar sprays of PGPR@ @ $20 \mathrm{ml} \mathrm{l}^{-1}$ water at $35 \mathrm{DAS}$ and the flowering stage was beneficial and advisable for obtain higher growth parameters (plant height, branches and drymatter), yield attributes, yields, net returns, B:C ratio, protein content in seed and nutrient uptake of soybean under black cotton soils of Madhya Pradesh.

\section{REFERENCES}

Anonymous, 2019-20. The United States Department of Agriculture 2019-20. Available at www.usda.gov.

Anonymous, 2018. Soybean Processors Association of India (SOPA). www.sopa.org.

Anonymous, 1960. Association of Official Agricultural Chemistry (AOAC). Official methods of analysis, $9^{\text {th }}$ edn., Washington, DC.

Arora, V.K., Singh, C.B., Sidhu, A.S., Thind, S.S., 2011. Irrigation, tillage and mulching effects on soybean yield and water productivity in relation to soil texture. Agricultural Water Management 98(4), 563-568.

Bhanwariya, B., Ram, M., Kumawat, N., Kumar, R., 2013. Influence of fertility levels and biofertilizers growth and yield of linseed (Linum usitatissimum L.) under rainfed condition of south Gujarat. Madras Agricultural Journal 100(4-6), 403-406.

Carter, M.R., Rennie, D.A., 1984. Crop utilization of placed and broadcast ${ }^{15} \mathrm{~N}$-urea fertilizer under zero and conventional tillage. Canadian Journal of Soil Science 64, 563-570.

Dhyani, V.C., Kumar, R., Pandey, D.S., Singh, V.P., Singh, I.P., Sharma, Y., Chaturvedi, S., 2016. Improving productivity of wheat through mulching and foliar nutrition in late sown wheat. International Journal of Bio-resource and Stress Management 7(5), 990-995.

Gomez, K.A., Gomez, A.A., 1984. Statistical procedure for agricultural research, $2^{\text {nd }}$ Edn. John Wiley \& Sons, New York, 241-271.

Htwe, A.Z., Moh, S.M., Soe, K.M., Moe, K., Yamakawa, T., 2019. Effects of biofertilizer produced from Bradyrbizobium and Streptomyces griseoflavus on plant growth, nodulation, nitrogen fixation, nutrient uptake, and seed yield of mungbean, cowpea, and soybean. Agronomy 9(2), 1-12.

Jadav, M.L., Raidas, D.K., Kumawat, N., Girothia, O.P., Bhagat, D.V., Choudhary, S.K., 2021. Pigeonpea (Cajanus cajan L.) growth, yield and monetary influenced by drip irrigation and mulch in Vertisols of Madhya Pradesh. Legume Research, DOI: 10.18805/ LR-4701

Jain, R.C., 2015. Effect of integrated nutrient management and mulching on growth and yield of soybean [Glycine $\max ($ L.) Merrill] in clay loam soil. Current World Environment 10(2), 710-714.

Kalegore, N.K., Gavhane, M.A., Bhusari, S.A., Kasle, S.V., Dhamane, R.S., 2018. Response of cowpea (Vigna unguiculata) to inorganic and biofertilizers. International Journal of Economic Plants 5(4), 167-169. 
Khandkar, U.R., Tiwari, S.C., Kumawat, N., Awani, K.A., Bangar, K.S., Singh, S.P., 2019. Response of micronutrients, organics and biofertilizers on growth and yield of soybean under Vertisols. Journal of Experimental Zoology 20(10), 108-111.

Kumar, A., Meen, R.S., De, N., Gurjar D.S., Singh A., Yadav G., Pradhan, G., 2020a. Response of polymers and biofertilizers on soybean (Glycine max) yield under rainfed condition. Indian Journal of Agricultural Sciences 90(4), 767-770.

Kumar, A., Singh, S.S., Kumar, R., Kumawat, N., Singh, A.K., 2010. Response of Rhizobium and different levels of molybdenum on growth, nodulation and yield of black gram (Vigna mungo L.). Environment and Ecology 28(3A), 1728-1730.

Kumar, R., Chatterjee, D., Kumawat, N., Pandey, A., Roy, A., Kumar, M., 2014a. Productivity, quality and soil health as influenced by lime in ricebean cultivars in foothills of Northeastern India. The Crop Journal 2(5), 338-344.

Kumar, R., Deka, B.C., Kumawat, N., Ngachan, S.V., 2014 b. Effect of integrated nutrition, biofertilizers and zinc on production potential and profitability of garden pea (Pisum sativum L.) in eastern Himalaya, India. Legume Research 37(6), 614-620.

Kumar, R., Deka, B.C., Kumawat, N., Thirugnanavel, A., 2020b. Effect of integrated nutrition on productivity, profitability and quality of french bean (Phaseolus vulgaris). Indian Journal of Agricultural Sciences 90(2), 431-435.

Kumar, R., Saurabh, K., Kumawat, N., Sundaram, P.K., Mishra, J.S., Singh, D.K., Hans, H., Krishna, B., Bhatt, B.P., 2021. Sustaining productivity through integrated use of microbes in agriculture. In: Seneviratne, G., Zavahir, J.S. (Eds), Role of microbial communities for sustainability. microorganisms for sustainability, vol 29. Springer, Singapore, pp. 109-145. https:// doi.org/10.1007/978-981-15-9912-5_5

Kumawat, N., Kumar, R., Khandkar, U.R., Yadav, R.K., Dotaniya, M.L., Mishra, J.S., Hans, H., 2019. Silicon $(\mathrm{Si})$ and zinc $(\mathrm{Zn})$ solubilizing microbes: role in sustainable agriculture. biofertilizers for sustainable agriculture and environment. In: Giri, B. (Eds.), Biofertilizers for Sustainable Agriculture and Environment. Soil Biology 55, 109-135. https://doi. org/10.1007/978-3-030-18933-4_6.

Kumawat, N., Kumar, R., Kumar, S., Meena, V.S., 2017. Nutrient solibilizing microbes (NSMs): Its role in sustainable crop production. agriculturally important microbes for sustainable agriculture, Meena, V.S., Mishra, P.K., Bisht, J.K., Pattanayak, A. (Eds.) Springer Nature Singapore Pte Ltd ISBN 978-981-
10-5343-6, pp 25-61.

Kumawat, N., Singh, R.P., Kumar, R., Yadav, T.P., 2015. Effect of integrated nutrient management on productivity, nutrient uptake and economics of rainfed pigeonpea (Cajanus cajan) and blackgram (Vigna mungo) intercropping system. Indian Journal of Agricultural Sciences 85(2), 171-176.

Kumawat, N., Tiwari, S.C., Bangar, K.S., Khandkar, U.R., Awani, K., Yadav, R.K., 2021. Influence of different sources of plant nutrients on soil fertility, nutrient uptake and productivity of soybean under Vertisols. Legume Research 44(5), 556-561.

Kumawat, N., Yadav, R.K., Singh, M., Dudwe, T.S., Tomar, I.S., 2020. Effect of phosphorus and bioinoculants and their residual effect on succeeding chickpea (Cicer arietinum) cropping system. Indian Journal of Agricultural Sciences 90(2), 320-325.

Praharaj, C.S., Jat, R.L., Singh, S.S., Singh, N.P., 2020. Enhancing farm income and system productivity in soybean-lentil through land configuration, conservation tillage, seed priming and mulching under rainfed central India. Journal of Food Legume 33(1), 41-47.

Praharaj, C.S., Singh, S.S., Jat, R.L., Singh, U., Singh, N.P., Elanchezhian, R., Singh, R.P., 2017. Pulses based systems for sustaining soybean in Central India. Indian Farming 67(05), 02-05.

Rahangdale, N., Kumawat, N., Jadav, M.L., Singh, M., Bhagat, D.V., 2021. Effect of liquid bioinoculants and straw mulch on health of vertisols and productivity of soybean (Glycine max). Crop Research 56(3\&4), 111-117.

Rinku, Shekhawat, P.S., Kumawat, N., 2016. Influence of nitrogen levels and biofertilizers on yield, economics and nutrient uptake of pearl millet (Pennisetum glaucum L.) under rainfed conditions. Environment and Ecology 34(4A), 1839-1842.

Sekhon, N.K., Hira, G.S., Sidhu, A.S., Thind, S.S., 2006. Response of soybean (Glycine max Mer.) to wheat straw mulching in different cropping seasons. Soil Use and Management 21(4), 422-426.

Siczek, A., Horn, R., Lipiec, J., Usowicz, B., Lukowski, M., 2015. Effects of soil deformation and surface mulching on soil physical properties and soybean response related to weather conditions. Soil and Tillage Research 153, 175-84.

Sikka, R., Deol, J.S., Kaur, J., Singh, D., 2018. Effect of sowing dates, mulching and seed rates on nutrient uptake and productivity of soybean in sub - humid Punjab, India. Legume Research 41, 750-754.

Singh, N., Kushwaha, H.S., Singh, A., 2020. Integrated nutrient management on growth, yield, nutrient 
uptake and fertility balance in soybean (Glycine max L.) - wheat (Triticum aestivum L.) cropping sequence. International Journal of Bio-resource and Stress Management 11(4), 405-413.

Tomar, I.S., Yadav, R.K., Tripathi, R.K., Singh, M., Kumawat, N., Morya, J., 2018. Effect of nutrient management on soybean production. Journal of AgriSearch 5(2), 96-99.

Verma, G., Singh, M., Morya, J., Kumawat, N., 2017. Effect of $\mathrm{N}, \mathrm{P}$ and biofertilizers on growth attributes and yields of mungbean [Vigna radiata (L.) Wilczek] under semi-arid tract of Central India. International Archive of Applied Sciences and Technology 8(2), 31-34.

Virk, H.K., Singh, G., Sharma, P., 2018b. Symbiotic parameters, growth, nutrient uptake as influenced by biofertilizers under conservation agriculture practices. Proceedings of Indian Academy Sciences Section B: Biological Sciences 88(4),1453-1461.

Virk, H.K., Singh, G., Manes, G.S., 2018a. Growth, symbiosis, productivity, and profitability of soybean at varying planting methods and nitrogen levels. Journal of Plant Nutrition 41(9), 1184-1196.

Virk, H.K., Singh, G., Manes, G.S., 2019. Nutrient uptake, nitrogen use efficiencies, and energy indices in soybean under various tillage systems with crop residue and nitrogen levels after combine harvested wheat, Journal of Plant Nutrition, DOI: 10.1080/01904167.2019.1683190. 